\title{
Histological and Ultrastructural Characterization of the Gonads of the Grunting Toadfish Allenbatrachus grunniens (Linnaeus, 1758) from the Pranburi River Estuary, Thailand
}

\author{
Tappadit Mitparian $^{1}$, Sinlapachai Senarat ${ }^{2}$, Jes Kettratad ${ }^{1, *}$, \\ Wannee Jiraungkoorskul, ${ }^{3,4}$, Gen Kaneko ${ }^{5}$, \\ Niwat Kangwanrangsan $^{4}$ and Sumate Ampawong ${ }^{6}$
}

\author{
${ }^{1}$ Department of Marine Science, Faculty of Science, Chulalongkorn University, Bangkok 10330, Thailand \\ ${ }^{2}$ Department of Marine Science and Environment, Faculty of Science and Fisheries Technology, \\ Rajamangala University of Technology Srivijaya, Trang 92150, Thailand \\ ${ }^{3}$ Division of Pathology, Preclinical Health Science Center, Faculty of Medicine, \\ Bangkokthonburi University, Bangkok 10170, Thailand \\ ${ }^{4}$ Department of Pathobiology, Faculty of Science, Mahidol University, Bangkok 10400, Thailand \\ ${ }^{5}$ School of Arts and Sciences, University of Houston - Victoria, Texas 77901, USA \\ ${ }^{6}$ Department of Tropical Pathology, Faculty of Tropical Medicine, Mahidol University, \\ Bangkok 10400, Thailand
}

("Corresponding author's e-mail: Jes.K@chula.ac.th)

Received: 4 August 2020, Revised: 22 March 2021, Accepted: 31 March 2021

\begin{abstract}
Information on the reproductive biology of toadfish remains limited. In this study, we examined the structure and development of gonads in the grunting toadfish Allenbatrachus grunniens (Linnaeus, 1758) using morphological, histological and ultrastructural methods. The fish were collected from the Pranburi River Estuary, Thailand, during the annual reproductive period for this species (January to December 2018). The ovary of this species was paired and had elongated sac-like structures parallel to the kidneys and the digestive tract. In females, we identified 4 oocyte differentiation phases in the ovary including oogonia proliferation phase, a primary growth phase that was further classified into 2 steps (perinucleolar and oil droplets-cortical alveolar steps), and a secondary growth phase that also contained 2 steps (secondary growth and full-grown oocyte steps) and post-ovulatory phases, indicating an asynchronous pattern in ovarian development for this species. Transmission electron microscopy showed the 4 layers including the zona pellucida, basement membrane, granulosa cells and theca cells, all of which initially appeared in the oil droplets-cortical alveolar stage. The zona pellucida and the granulosa cells were highly developed during the secondary growth stage. The granulosa cells contained abundant smooth endoplasmic reticulum near the mitochondria. In males, the spermatogenesis was classified into spermatogonium to spermatozoa. Finally, we associated the morphological gonadal developments (stage I - IV) and the gonadosomatic index (GSI value) with the cellular developmental processes in both sexes. These results help integrate various levels of reproductive observations, which will be applied to understanding the reproductive cycle and development for aquaculture.
\end{abstract}

Keywords: Batrachoididae, Histology, Oocytes, Reproductive cycle, Sperm, Thailand

\section{Introduction}

The family Batrachoididae is composed of 3 sub-families containing 69 toadfish species, all of which have limited information on their reproductive biology. Several early observations include an oocyte development study on the Lusitanian toadfish Halobatrachus didactylus, which classified its oocyte development into previtellogenic and vitellogenic stages [1]. The classification of oocyte development into 4 stages (oogonia, previtellogenic, vitellogenic and post-ovulatory) has also been documented in $H$. didactylus [2,3]. However, such cellular level information has not been well characterized with external morphology in toadfish. In other teleosts, oocyte development is usually identified along with structural characteristics of the gonads [4-7], providing useful endpoints for the 
determination of reproductive dynamics and the accurate assessment of reproductive cycles in natural and managed habitats.

The grunting toadfish Allenbatrachus grunniens (Linnaeus, 1758), which belongs to the family Batrachoididae, is an economically important estuarine fish species in Thailand and other South Asian countries, which supports the seafood industry and local fishing communities. This fish also has substantial potential as a candidate aquaculture species, but the structural information on the gonadal development is still missing. In the present study, we described the gonadal histology along with its development for A. grunniens at histological and ultrastructural levels. We further associated the cellular level information with the external morphology of gonads for future application in ecological monitoring and aquaculture of this species.

\section{Materials and methods}

Fish collection and study area

A total of 111 healthy specimens of $A$. grunniens with the total length of $30.70 \pm 1.23$ (SD) mm and body weight of $60.20 \pm 1.03 \mathrm{~g}$ were caught during January to December 2018 from the Pranburi River estuary, Thailand (N12 $\left.24.314^{\prime} \mathrm{E} 99^{\circ} 58.597^{\prime}\right)$. The experimental protocol was approved by the Animal Care and Use Committee of Faculty of Science in accordance with the guide for the care and use of laboratory animals prepared by Chulalongkorn University (Protocol Review No. 1723004).

\section{Observation of gonadal structure and gravimetric analysis}

All fish were euthanized by rapid cooling shock [8]. Their abdominal cavities were then longitudinally dissected and the reproductive systems (ovary and reproductive ducts) were morphologically observed for visual characters including position, shape and colorization, which were photographed using a digital camera (Canon EOS 550). Subsequently, each whole gonad was weighted to an accuracy of $0.01 \mathrm{~g}$ [9] for calculating the gonadosomatic indices (GSI) using the formula GSI = [ovarian weight/total weight $\times 100$ ]. This gravimetric valve was used for the determination of gonadal development/maturation $[10,11]$.

\section{Histological and histochemical observation}

Ovaries were fixed in Davidson's fixative for $24 \mathrm{~h}$ and then transferred to $70 \%$ ethanol. After fixation, they were cut into small pieces $\left(1 \times 1 \mathrm{~cm}^{2}\right)$ from anterior, middle and posterior areas and then processed according to standardized histological procedures [12,13]. Paraffin-embedded sections of $4 \mu \mathrm{m}$ thickness were stained with the routine haematoxylin-eosin (H\&E) to observe the basic gonadal structure and gametogenic differentiation. Masson's trichrome (MAT) staining was used to identify the connective/fiber structures [12,13]. All histological sections were examined under a light microscope according to Uribe et al. [14]. The histological images were taken with a Leica DM750 light microscope (Leica Industries, Inc; Germany). Oocyte size was determined from 3 sections per sample [about 50 cells per section at magnifications of $40 \times$ for oogonium and $10 \times$ for other oocyte stages] and represented as mean \pm SD. The process of gonadal development was classified based on the proportion of germ cells with minor modifications from previous criteria $[15,16]$. The gamete proportion was visually assessed and presented as a percent proportion.

\section{Lipid distribution in the ovary}

To investigate lipid distribution, fresh ovaries $(n=10)$ were fragmented into small pieces of approximately $1 \mathrm{~cm}$ and then sectioned at $10 \mu \mathrm{m}$ thicknesses. The frozen sections were stained with oil red O (ORO) [17]. Distribution of lipid droplets in oocytes was observed and photographed with a Leica DM750 light microscope.

\section{Ultrastructural observation}

To investigate the fine follicular structure, fragmented oocytes $(n=3)$ in the primary and secondary growth phases were cut into small pieces and immersed in $2.5 \%$ glutaraldehyde in $0.1 \mathrm{M}$ phosphate buffer, pH 7.4 at $4{ }^{\circ} \mathrm{C}$ overnight. After washing in the same buffer, the tissues were post-fixed in $1 \%$ osmium tetroxide $\left(\mathrm{OsO}_{4}\right)$ and then processed with respect to the standard ultrastructural protocol [18]. Ultrathin sections (about $90 \mathrm{~nm}$ thickness) were cut, stained with $2 \%$ uranyl acetate and lead citrate, and observed with a transmission electron microscopy (TEM Philips/TECNAI 20). 


\section{Results and discussion}

Gross morphology and histology of the female reproductive system

The female reproductive system of A. grunniens was located dorsally to the digestive tract, composing of the oviduct and a paired ovary with a sac-like oval shape. The ovary had a color ranging from yellow to orange due to the presence of mature oocytes (Figures 1A - 1B). The ovary of $A$. grunniens was surrounded by a thick layer of tunica albuginea (Figure 1C). Within the ovarian parenchyma, 2 regions, cortex and medullar, were clearly identified (Figure 1C). The loose connective tissue was the major component of the medullar region, whereas the formation of oocytes was observed in the cortex region (Figure 1C). In this study, we classified the oocyte differentiation of A. grunniens into 4 phases including oogonia proliferation $(\mathrm{Op}$ ) phase, primary growth $(\mathrm{PG})$ phase, secondary growth (SG) phase, and post-ovulatory ( $\mathrm{PO}$ ) phases based on cell size, shape, folliculogenesis and histological features. The overall characteristics were similar to those observed from $\mathrm{H}$. didactylus and other fishes [7,19-22].

\section{Oogonia proliferation (Op)}

The smallest oocyte type observed in this study was the oogonia (Og) in the Op phase, which had a diameter of $12 \pm 0.87 \mu \mathrm{m}(\mathrm{n}=50)$. This cell had an oval to rounded shape and was located close to the germinal epithelium (Figure 1D). The nucleus of a spherical shape was enclosed by the eosinophilic cytoplasm. The follicle layer was not easily observed during the Op phase. Such oogonial structures are similar to those observed in other teleosts $[23,24]$

\section{Primary growth (PG) phase}

We classified the PG phase into the perinucleolar $(\mathrm{Pn})$ and oil droplet-cortical alveolar (Oc) steps (Figures 1E - 1F). At the beginning of the Pn step, the oocyte increased the diameter to $50.2 \pm 0.98 \mu \mathrm{m}$ with a central nucleus of about $25 \mu \mathrm{m}(\mathrm{n}=50)$. A strong basophilic staining was observed in the cytoplasm, which is a characteristic of a period of intense RNA synthesis associated with ribosome production to support oocyte development [25]. The follicle cell layer started to form with the elongated fibroblast-like cells completely covering the oocyte (Figure 1E). This feature is quite similar to that reported in the dusky grouper Epinephelus marginatus [26], the Pacific bluefin tuna Thunnus orientalis [27], and the Atlantic bluefin tuna T. thynnus [28].

In the Oc step, the oocyte further increased the size to $120 \pm 0.53 \mu \mathrm{m}(\mathrm{n}=50)$. The accumulation of oil droplets and cortical alveoli was first observed in this step (Figure 1G). The lipid droplets provide energy for embryonic development [29], whereas the role of the cortical alveoli is suggested to be the prevention of polyspermy after ovulation [30]. As follicular development progresses, it became clear that the follicular complex consisted of 3 layers: Zona pellucida, granulosa cells and theca cells. The acidophilic zona pellucida was a relatively thin layer of about $2-3 \mu \mathrm{m}$ thickness. Granulosa cells and theca cells each formed a single layer (Figure 1H), and the basement membrane was present between the 2 layers (Figure 1I). It was confirmed by TEM observation that the zona pellucida had longer microvilli associated with granulosa cells (Figure 1J). Several mitochondria and SER were observed in the granulosa and theca cells (Figures 1J - 1K). 


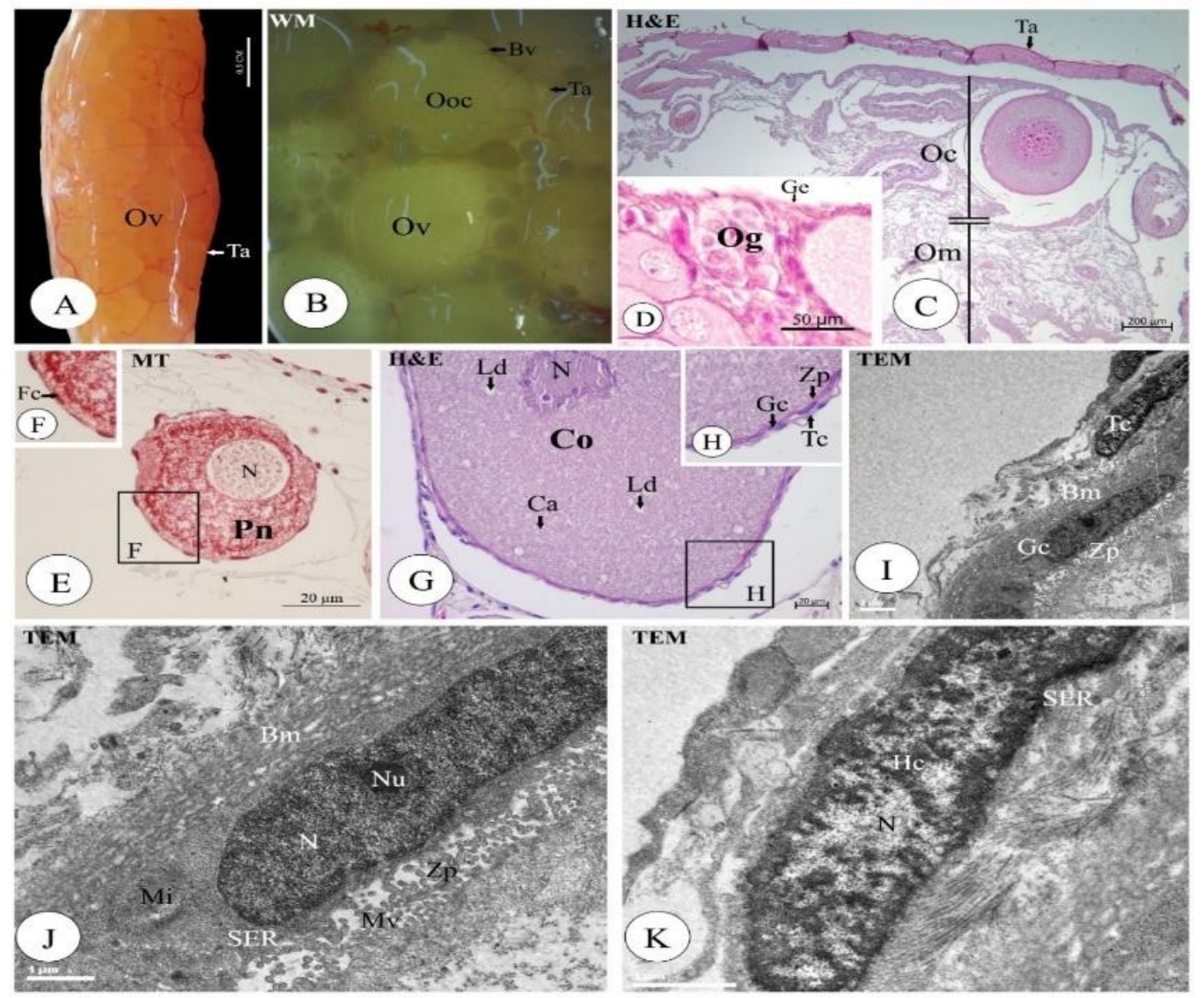

Figure 1 A - B; morphology, C - H; light photomicrograph of the ovarian structure (Ov) and I - K; electron micrograph of follicular complex of Allenbatrachus grunniens.

Abbreviations: $\mathrm{Bm}=$ basement membrane, $\mathrm{Bv}=$ blood vessel, $\mathrm{Ca}=$ cortical alveoli, $\mathrm{Co}=$ cortical alveolar and lipid droplet stage, $\mathrm{Fe}=$ follicle cell, $\mathrm{Gc}=$ granulosa cell, $\mathrm{Ge}=$ germinal epithelium, $\mathrm{Gm}=$ germinal compartment, $\mathrm{Hc}=$ heterochromatin, $\mathrm{Ld}=$ lipid droplet, $\mathrm{Mi}=$ mitochondria, $\mathrm{Mv}=$ microvilli, $\mathrm{N}$ $=$ nucleus, $\mathrm{Nu}=$ nucleolus, $\mathrm{Oc}=$ ovarian cortex, $\mathrm{Og}=$ oogonia, $\mathrm{Om}=$ ovarian medulla, Ooc $=$ developing oocytes, $\mathrm{Pn}=$ perinucleolar stage, Ta $=$ tunica albuginea, $\mathrm{Tc}=$ theca cell, $\mathrm{SER}=$ smooth endoplasmic reticulum, $\mathrm{Zp}=$ zona pellucida.

Observation and staining methods: $\mathrm{H} \& \mathrm{E}=$ Hematoxylin and Eosin, $\mathrm{MT}=$ Masson's trichrome, $\mathrm{TEM}=$ transmission electron microscope, $\mathrm{WM}=$ whole mount.

\section{Secondary growth (SG) phase}

The SG phase is classified into 2 steps including the secondary growth $(\mathrm{Sg})$ step and full-grown oocyte (Fgo) step [14]. Oocytes in the Sg step continuously increased the diameter up to $604 \pm 1.22 \mu \mathrm{m}$ $(n=50)$ with an extensive accumulation of yolk granules (Figures 2 A - 2B). A centrally located nucleus was identified (Figure 2A). The small oil droplets fused, and cortical alveoli were widely scattered within the follicular complex (data not shown). The yolk granule was heterogenous under TEM observation, containing small electron-dense granules in the matrix (Figures 2C - 2E). In parallel to the welldeveloped ultrastructure of pore of microvilli, abundant finger-shaped cytoplasmic projections from the granulosa cells to the zona pellucida were noted (Figure 2F) with a maximum thickness of 3 nm (Figure 2G). 

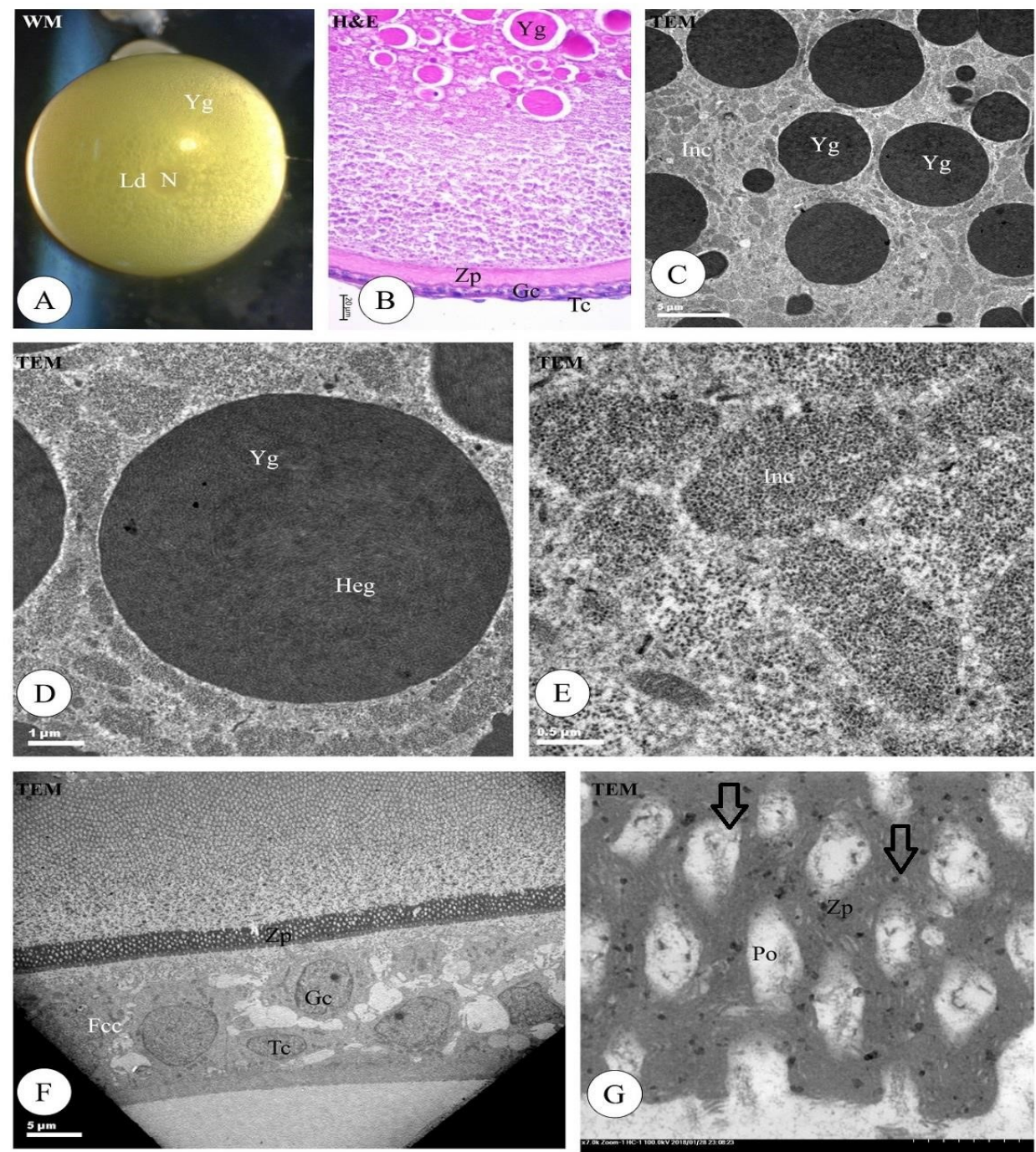

Figure 2 A; morphology, B; light photomicrograph and C - G; electron micrograph of the secondary growth phase oocytes of Allenbatrachus grunniens.

Abbreviations: $\mathrm{Fcc}=$ follicular complex, $\mathrm{Gc}=$ granulosa cell, $\mathrm{Heg}=$ heterogeneous, $\mathrm{Inc}=$ intracellular matrix, $\mathrm{Ld}=$ lipid droplet, $\mathrm{N}=$ nucleus, $\mathrm{Po}=$ pore of microvilli, $\mathrm{Tc}=$ theca cell, $\mathrm{Yg}=$ yolk granule, $\mathrm{Zp}=$ zona pellucida, arrows $=$ finger-like extensions of the granulosa cells.

Observation and staining method: $\mathrm{H} \& \mathrm{E}=$ Hematoxylin and Eosin, $\mathrm{TEM}=$ transmission electron microscope, $\mathrm{WM}=$ whole mount.

The single-layer of granulosa cells was well-organized and became thicker during the SG phase (Figures 3A - 3B). At higher magnification, the dilated SER and prominent mitochondria were observed in the granulosa (Figure 3B) and theca (Figures 3C - 3D) cells. The striated zona pellucida became considerably thicker than that of the previous stage, which was still adjacent to the granulosa and theca cell layers (Figure 3C). These 2 major follicle cell layers (granulosa cells and thecal cells) are capable of producing ovarian steroid hormones [30-33] as confirmed in several fishes of different orders such as Labriformes [34], Perciformes [35] and Siluriformes [36]. In this study, the prominent change in granulosa cells took place at the late SG phase, in which SER became prominent and number of mitochondria per cell dramatically increased. These results suggest that the granulosa cells may be the major site of steroid synthesis in A. grunniens. This is consistent with a report by Voorhis [37] who postulated that granulosa cells play a major role in estrogen production, whereas androgen production was restricted in theca cells. However, it is noted that the activity of granulosa and theca cells can be transformed during oocyte development in some teleosts including brook trout Salvelinus fontinalis [38], coho salmon Oncorhynchus kisutch [39], white-spotted char Salvelinus leucomaenis [40], and shortfin 
silverside Chirostoma humboldtianum [41]. It would therefore be of interest to further investigate granulosa activity in the follicular complex in A. grunniens. Indeed, an in vitro experiment using isolated follicle cell layers has shown that the granulosa cells are steroidogenicly responsible for the production of estradiol-17 $\beta$ during vitellogenesis $[42,43]$.
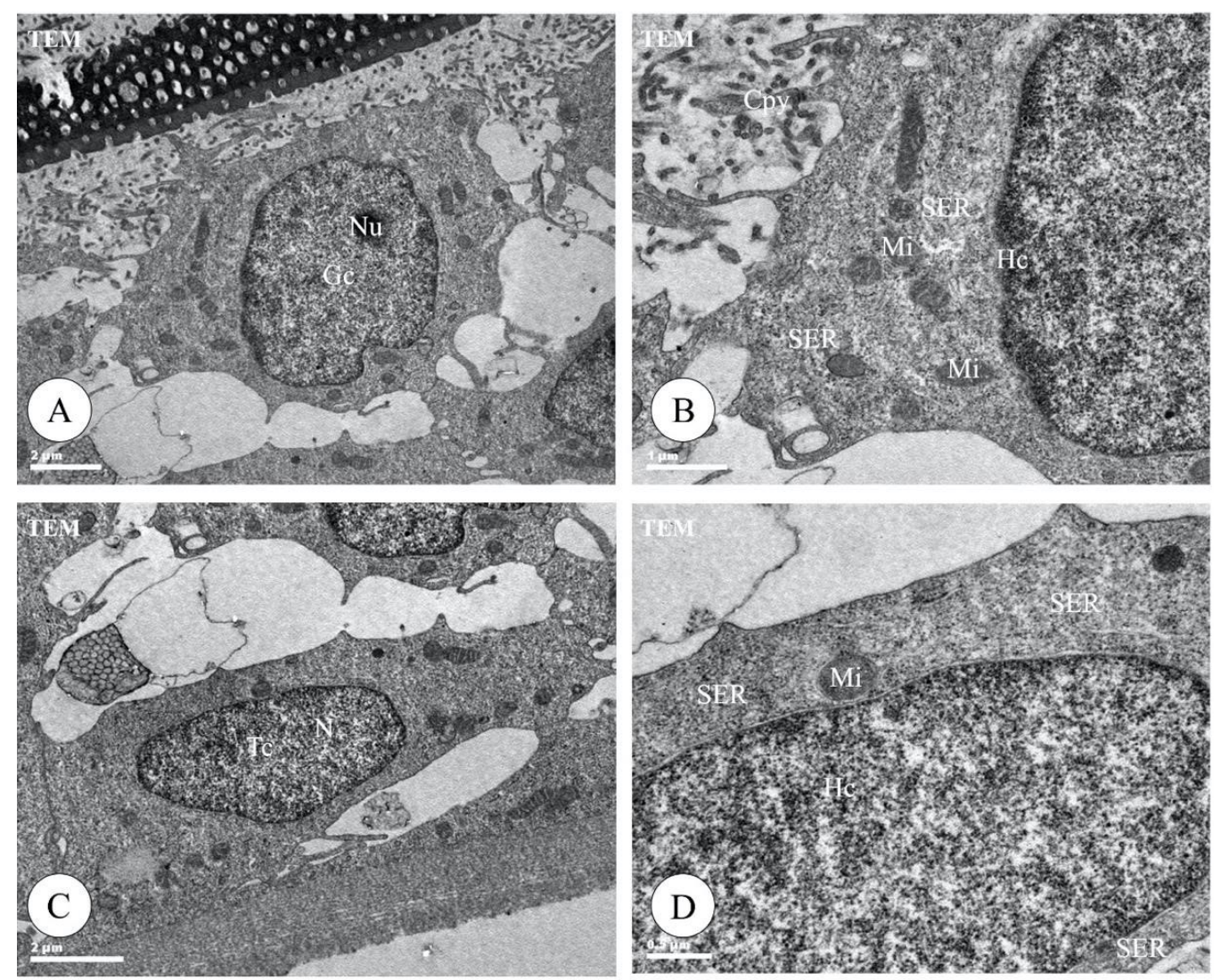

Figure 3 A - B; higher magnification of electron micrograph of the granulosa cells (Gc) and C - D; theca cells (Tc) of Allenbatrachus grunniens.

Abbreviations: $\mathrm{Cpy}=$ cytoplasmic process, $\mathrm{Hc}=$ heterochromatin, $\mathrm{Mi}=$ mitochondria, $\mathrm{N}=$ nucleus, $\mathrm{Nuc}=$ nucleolus, $\mathrm{SER}=$ smooth endoplasmic reticulum.

The maximum oocyte size of $1200 \pm 1.82 \mu \mathrm{m}$ was observed in the Fgo step (Figure 4A), which is the final step of oogenic development. The nucleus was absent (Figure 4A), and the yolk globules were completely fused (Figures 4B - 4C). Many lipid droplets were detected by ORO exclusively in parallel to the follicular complex (Figure 4D). The follicular complex appeared to be similar is that in the previous $\mathrm{Sg}$ step, but the theca cells were enlarged in this step (Figure 4E).

\section{Post-ovulatory (PO) phase}

The PO phase oocytes were accompanied by a stratified follicle cell layer of an irregular shape (Figure 4F). This was the remaining structure of the ovary after the release of the ovum during spawning. From the presence of oocytes in the PO phase in our samples, we can speculate that A. grunniens spend their entire life cycle in the estuary as an obligate estuarine species. 

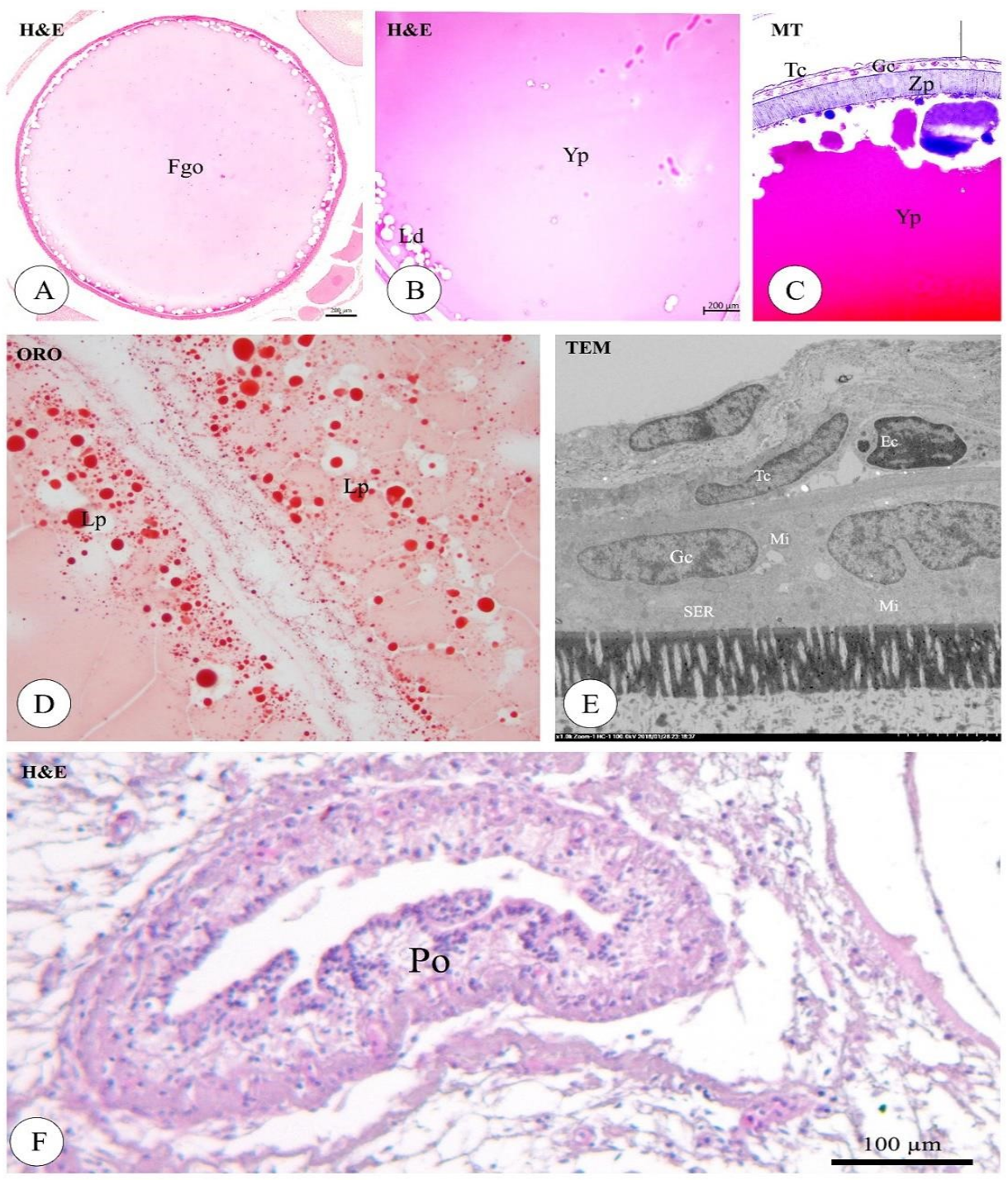

Figure 4 A - E; structural characteristics of full-growth oocytes and F; post-ovulatory follicle of Allenbatrachus grunniens.

Abbreviations: $\mathrm{Ec}=$ erythrocyte, $\mathrm{Gc}=$ granulosa cell, $\mathrm{Ld}=$ lipid droplet, $\mathrm{Mi}=$ mitochondria, $\mathrm{SER}=$ smooth endoplasmic reticulum, $\mathrm{Tc}=$ theca cell, $\mathrm{Yp}=$ yolk plate, $\mathrm{Zp}=$ zona pellucida.

Observation and staining methods: $\mathrm{H} \& \mathrm{E}=$ Hematoxylin and Eosin, $\mathrm{ORO}=$ oil red $\mathrm{O}, \mathrm{MT}=$ Masson's trichrome, TEM $=$ transmission electron microscope.

\section{Gross morphology and histology of the male reproductive system}

The male reproductive system is composed of a single and unpaired organ with testicular ducts. The tunica albuginea was similar to that observed in the ovary (Figures 5A - 5D). The testis had 2 compartments: Interstitial and germinal compartments (Figures 5D - 5E). The interstitial compartment protruded from the tunica albuginea. Fibroblasts, Leydig cells, and blood vessels were clearly observed (Figures 5F - 5G). Leydig cells had a spherical or irregular shape and were located in the connective tissue, and a deeply basophilic oval nucleus was clearly identified (Figures 5F - 5G). Leydig cells are known to produce major androgens and 11-ketotestosterone [30,44,45] as reported in the swamp eel Synbranchus senegalensis, freshwater goby Padogobius martensi [46] and marbled rockfish Sebastiscus marmoratus [47]. 

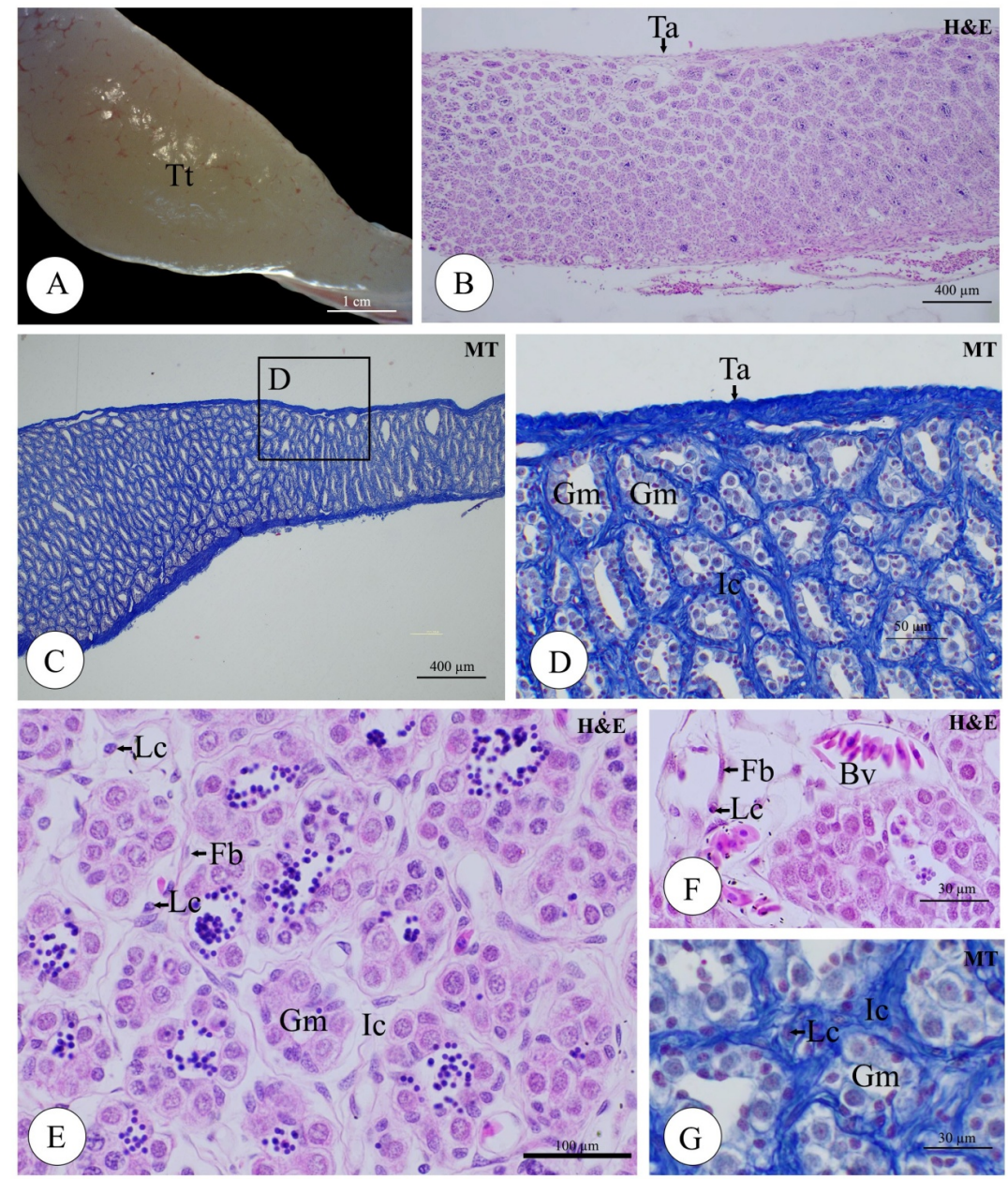

Figure 5 A; Morphology and B - G; light micrographs of testis of Allenbatrachus grunniens. It was covered by the thin tunica albuginea (Ta). Within the testicular parenchyma, there were 2 compartments including interstitial (Ic) and germinal (Gm) compartments.

Abbreviations: $\mathrm{Bv}=$ blood vessel, $\mathrm{Fb}=$ fibroblast, $\mathrm{Lc}=$ Leydig cell.

Staining methods: H\&E = Hematoxylin and Eosin, MT = Masson's trichrome.

Seminiferous lobules and Sertoli cells were identified in the germinal compartment (Figures 6A 6D). The Sertoli cells were generally located in the wall of seminiferous tubule (Figures 6C - 6D). The Sertoli cells directly contacted the germ cells, forming a germinal cyst-like structure. The testicular type of this fish was determined to be the unrestricted-spermatogonial testis type due to the distribution of spermatogonia along the lobule (Figures 6A - 6B). The spermatogenic process was divided into 3 distinct phases: Spermatogonial, spermatocyte and spermiogenetic phases (Figures 6B - 6H). Within their cysts, sperm cells of several stages were present similar to that reported in previous studies $[30,44,45]$.

The germinal cells in the spermatogonial phase are called spermatogonia $(\mathrm{Sg})$, which have the ability to undergo mitotic divisions. The Sg were exclusively found along the tubule (Figures 6C - 6D) with a large nucleus and light granular cytoplasm (Figure 6D) as generally seen in male vertebrates [48].

The distinctive feature of germinal cells in the spermatocyte phases is that the cells undergo meiotic divisions. Germinal cells in this stage were further classified into 2 types [primary spermatocytes (PS) and secondary spermatocytes (SS)] (Figure 6E). The PS was characterized by an ovoid shape and gradual clumps of nuclear chromatins (Figure 6F). The PS is known to be transformed into the SS through meiosis I. As a result, the SS are considerably smaller than PS, but SS was relatively rare in our histological sections. The chromatins were dramatically condensed and more basophilic in SS compared to PS, and their cytoplasm was scanty (Figure 6G). The duration of this stage is short in most teleosts [30,44]. 
The spermiogenetic phase is a phase characterized by the complex modification of cellular structure. Germinal cells in this phase were classified into sub-stages spermatid (St) and spermatozoa (Sz) (Figure 6H). The St showed a pronounced nuclear condensation and scant eosinophilic cytoplasm (Figure 6I). The spermatozoa were the smallest cell throughout the spermatogenic process consisting of a head and tail (Figure 6J).

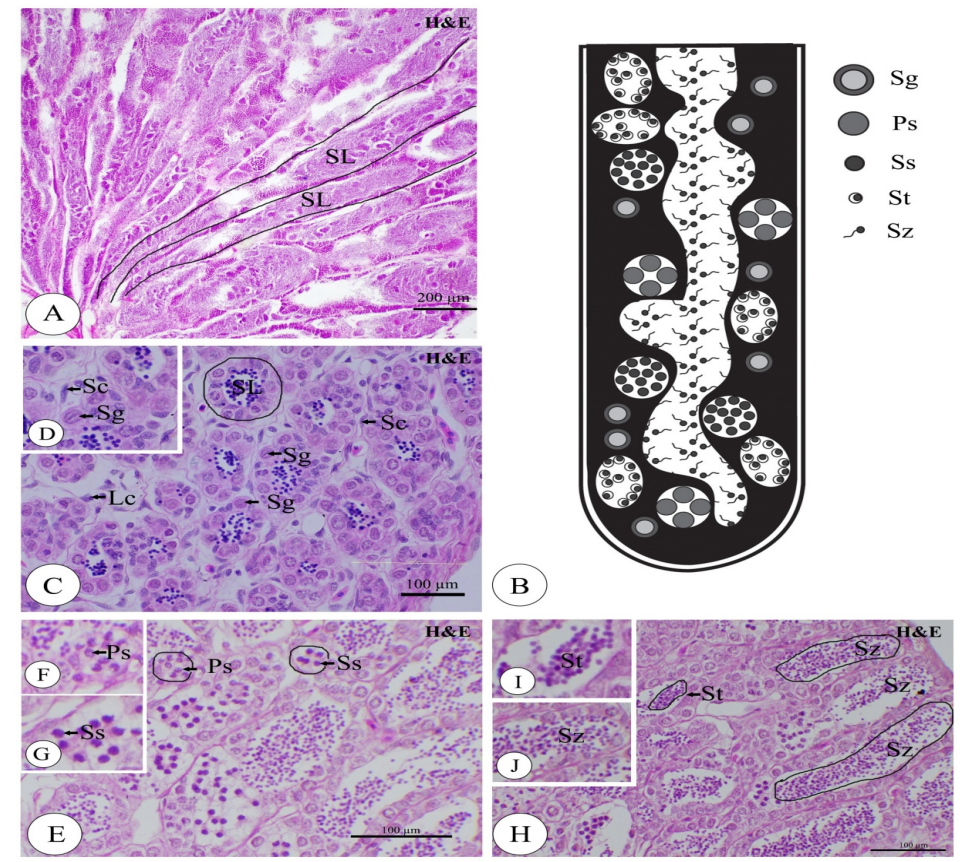

Figure 6 A, C - H; light microscope observation and B; the schematic diagram of the seminiferous lobule (SL) and spermatogenesis of Allenbatrachus grunniens. A - B; longitudinal sections identified the testis as the unrestricted spermatogonial type. $\mathrm{C}-\mathrm{H}$; cross sectional observations showed that the spermatogenesis of this species is classified into 5 stages including spermatogonium ( $\mathrm{Sg}$ ), primary spermatocytes (Ps), secondary spermatocytes (Ss), spermatids (St) and spermatozoa (Sz).

Abbreviations: $\mathrm{Lc}=$ Leydig cell, $\mathrm{Sc}=$ Sertoli cell.

Staining method: H\&E = Hematoxylin and Eosin.

\section{Characterization and gonadal development during annual reproductive cycle}

In this study, we classified the gonadal development of $A$. grunniens into 4 distinct stages: Stage 1 (undeveloped), tage 2 (early-development), stage 3 (late-development) and stage 4 (post-ovulatory). These features were categorized based on gonad color, the proportion of germ cells and histological characteristics (Table 1).

Table 1 Summary of morphological and histological observations of ovarian development of Allenbatrachus grunniens.

\begin{tabular}{|c|c|c|c|c|}
\hline Stages & Ovarian morphology & $\begin{array}{c}\text { Histology (main } \\
\text { developmental stages) }\end{array}$ & GSI & $\mathbf{N}$ \\
\hline $\begin{array}{c}\text { Stage I } \\
\text { (Undeveloped) }\end{array}$ & Whitish color & $\begin{array}{l}\text { Og and PG phase } \\
\text { (75\% proportion). }\end{array}$ & 0.07 & 1 \\
\hline $\begin{array}{c}\text { Stage II } \\
\text { (Early development) }\end{array}$ & $\begin{array}{c}\text { Much bigger than } \\
\text { stage I; Creamy white } \\
\text { color }\end{array}$ & $\begin{array}{l}\text { SG phase }(75 \%) \text {, but PG } \\
\text { phase oocytes were also } \\
\text { found. }\end{array}$ & $1.12 \pm 0.70$ & 22 \\
\hline $\begin{array}{c}\text { Stage III } \\
\text { (Late development) }\end{array}$ & $\begin{array}{l}\text { Deep yellow to } \\
\text { red/orange }\end{array}$ & $\begin{array}{c}\text { Fgo step in the SG phase } \\
(75 \%) .\end{array}$ & $5.38 \pm 3.27$ & 31 \\
\hline $\begin{array}{c}\text { Stage IV } \\
\text { (Post-ovulatory) }\end{array}$ & Creamy color & PO phase $(75 \%)$ & $2.00 \pm 0.04$ & 2 \\
\hline
\end{tabular}


Undeveloped stage

This stage was rarely found in samples used in this study. The ovaries were very small and had a rod-like shape with a creamy-white color (Figure 7A). Histological observations of ovaries in this stage found a small number of $\mathrm{Og}$ and a large amount of PG (75\% proportion) (Figure 7B). The lowest GSI of 0.07 was observed in samples of this stage (Table 1).

\section{Early-development stage}

The ovary was still in a milky to white color (Figure 7C), but its size was increased. The most dominant cells in the ovary of this stage were oocytes in the SG phase (75\% proportion), but some Og and PG phase oocytes were also identified (Figure 7D). The mean GSI of the ovary was markedly increased to $1.12 \pm 0.70$ in this stage (Table 1).
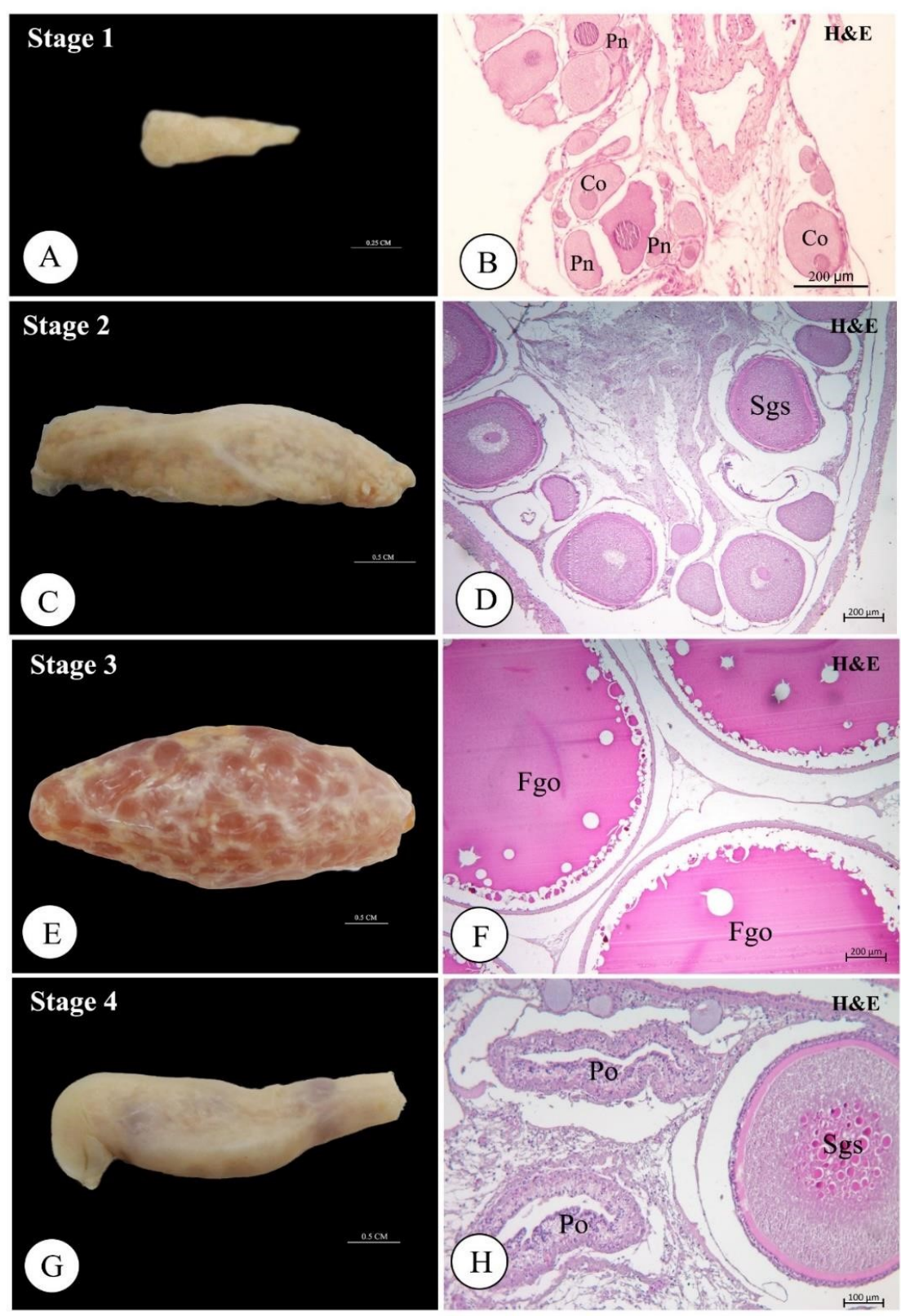

Figure 7 Association of external morphology and light microscope observation of the ovarian development of Allenbatrachus grunniens. Stage 1 (A - B; undeveloped), stage 2 (C - D; earlydevelopment), stage 3 (E - F; late-development) and stage 4 (C - H; post-ovulatory).

Abbreviations: $\mathrm{Co}=$ cortical alveoli and lipid droplet stage, $\mathrm{Fgo}=$ full growth stage, $\mathrm{Pn}=$ perinucleolar stage, $\mathrm{Sgs}=$ secondary growth stage. Staining method: $\mathrm{H} \& \mathrm{E}=$ Hematoxylin and Eosin. 


\section{Late development stage}

The ovary became bright orange in color (Figure 7E). The vast majority of developing oocytes were in the Fgo step of the SG phase (75\% proportion) (Figure 7F). Some oocytes were still in the PG phase and the Sg step of the SG phase. The GSI reached the highest value of $5.38 \pm 3.27$ in this stage (Table 1).

Post-ovulatory stage

The ovary turned to a white color (Figure 7G) represented by oocytes in the PO phase $(75 \%$ proportion) (Figure 7H), while a small amount of SG phase oocytes still existed (Figure 7H). A dramatic decrease in the GSl value (2.00 \pm 0.04$)$ was observed in this phase.

The testicular development of male A. grunniens was divided into following stages: Stage 0 (immature), stage 1 (early spermatogenic), stage 2 (mid-spermatogenic) and stage 3 (late spermatogenic).

\section{Immature stage}

The testis was very small and had a white color (Figure 8A). Only Sg (100\% proportion) was observed (Figure 8B), and the GSI was the lowest $(0.003 \pm 0.005)$ (Table 2).

\section{Early-spermatogenic stage}

The testis color was similar to that observed in the previous stage, but the testis gradually increased the size (Figure 8C). The Sg, PS and SS were present in roughly equal proportions with a small proportion of Sz (Figure 8D). The GSI value was about $0.048 \pm 0.126$ (Table 2).
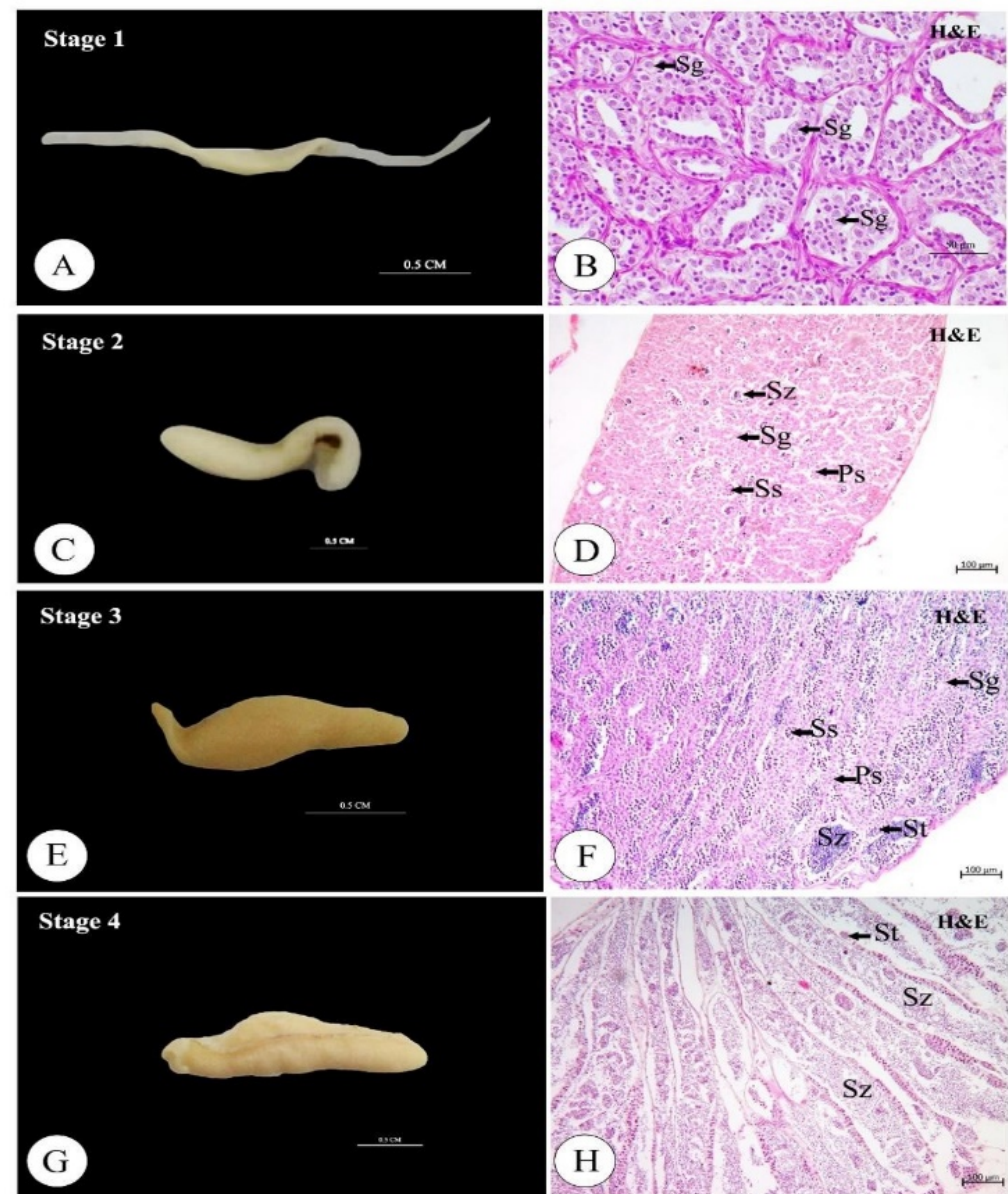

Figure 8 Association of external morphology and light microscope observation of the testicular development of Allenbatrachus grunniens: Stage 1 (A - B; immature), stage 2 (C - D; early spermatogenic), stage 3 (E - F; mid-spermatogenic) and stage 4 (G - H; late spermatogenic).

Abbreviations: $\mathrm{Ps}=$ primary spermatocyte, $\mathrm{Sg}=$ spermatogonium, $\mathrm{Ss}=$ secondary spermatocyte, $\mathrm{St}=$ spermatid, $\mathrm{Sz}=$ spermatozoa.

Staining method: H\&E = Hematoxylin and Eosin. 
Middle-spermatogenic stage

The testis became slightly colored and increased in size in this stage (Figure 8E). The proportion of $\mathrm{Sg}$ decreased, while those of Ps, Ss, St and especially Sz increased (Figure 8F), leading to the dramatic increase in the GSI value $(0.143 \pm 0.165)$ (Table 2).

Late -spermatogenic stage

The testis had a white to creamy color (Figure 8G). A high proportion of Sz ( $75 \%$ proportion) was found (Figure 8H). Sg to St cells were rare but still visible. The highest GSI value of $0.357 \pm 0.218$ was observed in this stage (Table 2).

Table 2 Summary of morphological and histological observations of testicular development of Allenbatrachus grunniens.

\begin{tabular}{ccccc}
\hline Stages & $\begin{array}{c}\text { Ovarian } \\
\text { morphology }\end{array}$ & $\begin{array}{c}\text { Histology } \\
\text { (main developmental stages) }\end{array}$ & GSI & N \\
\hline $\begin{array}{c}\text { Stage I } \\
\text { Immature) }\end{array}$ & Whitish color & Only Sg (100 \%) & $0.003 \pm 0.005$ & 2 \\
\hline $\begin{array}{c}\text { Stage II } \\
\text { (Early spermatogenic) }\end{array}$ & Creamy white color & $\begin{array}{c}\text { Sg, PS, SS (25 \% each) with a } \\
\text { small portion of SZ }\end{array}$ & $0.048 \pm 0.126$ & 29 \\
\hline $\begin{array}{c}\text { Stage III } \\
\text { (Mid-spermatogenic) }\end{array}$ & Bright orange & Sz (25 \%) & $0.143 \pm 0.165$ & 8 \\
\hline $\begin{array}{c}\text { Stage IV } \\
\text { (Late-spermatogenic) }\end{array}$ & Creamy white color & Sz (75 \%) & $0.357 \pm 0.218$ & 16 \\
\hline
\end{tabular}

\section{Conclusions}

In this study, we reported external morphology and GSI of the grunting toadfish A. grunniens in close association with the gonadal development for other teleosts. These findings will be useful for future assessments that incorporate reproductive parameters in the field or hatcheries where histological details cannot be obtained. Future studies can further aim to integrate these findings with vitellogenin and $17 \beta$ estradiol levels, which have been correlated with GSI. Such basic understandings of reproductive biology will contribute to more accurate assessments and conservation measures for sustainable management of this species.

\section{Acknowledgement}

This work was financially supported by the $90^{\text {th }}$ Anniversary of Chulalongkorn University Scholarship.

\section{References}

[1] JA Munoz-Cueto, M Alvarez, M Blanco, MLGD Canales, A Garcia-Garcia and C Sarasquete. Histochemical and biochemical study of lipids during the reproductive cycle of the toadfish, Halobatrachus didactylus (Schneider, 1801). Sci. Mar. 1996; 60, 289-96.

[2] A Arias and P Drake. Estados juveniles de la ictiofauna en los caños de las salinas de309 la Bahía de Cádiz. Instituto de Ciencias Marinas de Andalucía, Cádiz, Spain, 1990.

[3] MAB Rubio. Estudio histológico, histoquímico y bioquímico durante la reproducción del pez sapo, Halobatrachus didactylus, (Schneider, 1801) de la Bahía de Cádiz. Reprodut 1991; 123, 355-36.

[4] S Gupta. The development of carp gonads in warm water aquaria. J. Fish Biol. 1975; 7, 775-82.

[5] NK Al-Daham and MN Bhatti. Annual changes in the ovarian activity of the freshwater teleost, Barbus luteus (Heckel) from Southern Iraq. J. Fish Biol. 1979; 14, 381-7.

[6] I Mayer, SE Shackley and JS Ryland. Aspects of the reproductive biology of the bass, Dicentrarchus labrax L. I. An histological and histochemical study of oocyte development. J. Fish Biol. 1988; 33, 609-22.

[7] S Senarat, J Kettratad and W Jiraungkoorskul. Structure and ultrastructure of oogenic stage in short mackerel Rastrelliger brachysoma (Teleostei: Scombidae). J. Morphol. Sci. 2017; 34, 23-30 
[8] JM Wilson, RM Bunte and AJ Carty. Evaluation of rapid cooling and tricaine methanesulfonate (MS222) as methods of euthanasia in zebrafish (Danio rerio). J. Am. Assoc. Lab. Anim. Sci. 2009; 48, 785-9.

[9] M Moslemi-Aqdam, JI Namin, M Sattari, S Abdolmalaki, A Bani and B Rochowski. Reproductive characteristics of nothern pike, Esox lucius (Actinopterygii: Esociformes: Esocidae), in the Anzali Wetland, southwest Caspian Sea. Acta Ichthyologica et Piscatoria 2016; 46, 313-23.

[10] M King. Fisheries biology assessment and management. Fishing News Books, Oxford, 1995.

[11] I Sulistyo, P Fontaine, J Rincarh, JN Gardeur, H Migaud, B Capdeville and P Kestemont. Reproductive Cycle and Plasma Level of Steroid in Male Eurasian Perch (Perca fluviatilis). Aqua. Liv. Res. 2000; 13, 99-106.

[12] JK Presnell and MP Schreibman. Humason's animal tissue techniques. Johns Hopkins University Press, Maryland, 1997.

[13] KS Suvarnam, C Layton, and JD Bancroft. Bancroft's theory and practice of histological techniques. Churchill Livingstone, London, 2013.

[14] MC Uribe, HJ Grier and LR Parenti. Ovarian structure and oogenesis of the oviparous goodeids Crenichthys baileyi (Gilbert, 1893) and Empetrichthys latos Miller, 1948 (teleostei, Cyprinodontiformes). J. Morphol. 2012; 273, 371-87.

[15] D Dietrich and HO Krieger. Histological analysis of endocrine disruptive effects in small laboratory fish. John Wiley \& Sons, New Jersey, 2009.

[16] M Cassel, M Mehanna, L Mateus and A Ferreira. Gametogenesis and reproductive cycle of Melanorivulus aff. punctatus (Boulenger, 1895) (Cyprinodontiformes, Rivulidae) in Chapada dos Guimarães, Mato Grosso, Brazil. Neotrop. Ichthyol. 2013; 11, 179-92.

[17] CFA Culling. Handbook of histopathological and histochemical techniques: Including museum techniques. Butterworth-Heinemann, Oxford, 1974.

[18] G Rowden and MG Lewis. Experience with a three-hour electron microscopy biopsy service. J. Clin Pathol. 1974; 27, 505-10.

[19] J Lahaye. Les cycles sexuels chez les poissons marins. Oceanis 1980; 6, 637-54.

[20] RA Wallace and K Selman. Cellular and dynamic aspects of oocyte growth in teleosts. Am. Zool. $1981 ; 21,325-43$.

[21] K Selman and RA Wallace. Cellular aspects of oocyte growth in teleosts. Zool. Sci. 1989; 6, 211-31.

[22] S Senarat, J Kettratad and W Jiraungkoorskul. Testicular structure and spermatogenesis of short mackerel, Rastrelliger brachysoma (Bleeker, 1851) in The Upper Gulf of Thailand. Asia. Pac. J. Mol. Biol. Biotechnol. 2018; 26, 30-43.

[23] K Selman, RA Wallace, QI X and A Sarka. Stages of oocyte development in the zebra fish, Brachydanio rerio. J. Morphol. 1993; 218, 203-24.

[24] H Grier. Ovarian germinal epithelium and folliculogenesis in the common snook, Centropomus undecimalis (Teleostei: Centropomidae). J. Morphol, 2000; 243, 265-81.

[25] RA Wallace and K Selman. Ultrastructural aspects of oogenesis and oocyte growth in fish and amphibians. J. Electron. Microsc. Tech. 1990; 16, 175-201.

[26] A Mandich, A Massari, S Bottero and G Marino. Histological and histochemical study of female germ cell development in the dusky grouper Epinephelus marginatus (Lowe, 1834). Eur. J. Histochem. 2002; 46, 87-100.

[28] KS Chen, P Crone and CC Hsu. Reproductive biology of female Pacific bluefin tuna Thunnus orientalis from south-western North Pacific Ocean. Fish. Sci. 2006; 72, 985-94.

[29] C Sarasquete, S Cárdenas, MLGD Canales and E Pascual. Oogenesis in the bluefin tuna, Thunnus thynnus L.: A histological and histochemical study. Histol. Histopathol. 2002; 17, 775-88.

[30] M Wiegand. Composition, accumulation and utilization of yolk lipids in teleost fish. Rev. Fish Biol. Fish. 1996; 6, 259-86.

[31] Y Nagahama. The functional morphology of teleost gonads. In: WS Hoar, DJ Randall and EM Donaldson (Eds.). Fish physiology. Academic Press, New York, 1983, p. 223-75.

[32] SE Shackley and PE King. Oogenesis in a marine teleost, Blennius pholis L. Cell. Tissue. Res. 1977; 181, 105-28.

[33] Y Nagahama, H Kagawa and G Young. Cellular sources of sex steroids in teleost gonad. Can. J. Fish. Aquat. Sci. 1982; 39, 56-64.

[34] A Fostier, B Jalabert, R Billard, B Breton and Y Zohar. The gonadal steroids. In: WS Hoar, DJ Randall and EM Donaldson (Eds.). Fish physiology. Academic Press, New York, 1983, p. 277-372.

[35] AP Santos-Silva, DH Siqueira-Silva, A Ninhaus-Silveira and R Veríssimo-Silveira. Oogenesis in Laetacara araguaiae (Ottoni and Costa, 2009) (Labriformes: Cichlidae). Zygote 2015; 24, 502-10. 
[36] HJ Grier, CL Neidig and I Quagio-Grassiotto. Development and fate of the postovulatory follicle complex, postovulatory follicle, and observations on folliculogenesis and oocyte atresia in ovulated common snook, Centropomus undecimalis (Bloch, 1792). J. Morphol. 2017; 278, 547-62.

[37] JA Rodrigues-Filho, RM Honji, PH Mello, MI Borella, AWS Hilsdorf and RG Moreira. Reproductive biology of Pseudotocinclus tietensis (Siluriformes: Loricariidae: Hypoptopomatinae), a threatened fish species. Int. J. Aquat. Biol. 2017; 5, 218-27.

[38] BJV Voorhis. Follicular Steroidogenesis. Encyclopedia of reproduction. Vol II. Academic Press, Massachusetts, 1999, p. 389-95.

[39] H Fliigel. Licht und elektronenmikroskopische Untersuchungen an Oozyten und Eiern einiger Knochenfische. Zeitschrift für Zellforschung und Mikroskopische Anatomie 1967; 83, 82-116

[40] Y Nagahama, WC Clarke and WS Hoar. Ultrastructure of putative steroid-producing cells in the gonads of coho (Oncorhynchus kisutch) and pink salmon (Oncorhyzchzu gorhuscha). Can. J. Zool. 1978; 56, 2508-19.

[41] H Kagawa, K Takano and Y Nagahama. Correlation of plasma estradiol-17 $\beta$ and progesterone levels with ultrastructure and histochemistry of ovarian follicles in the white-spotted char, Salvelinus leucomaenis. Cell Tissue Res. 1981; 218, 315-29.

[42] R Cárdenas, M Chávez, JL González, P Aley, J Espinosa and LF Jiménez-García. Oocyte structure and ultrastructure in the Mexican silverside fish Chirostoma humboldtianum (Atheriniformes: Atherinopsidae). Rev. Biol. Trop. 2008; 56, 1371-80.

[43] G Young, H Ueda and Y Nagahama. Estradiol-17 alpha, 20 beta-dihydroxy-4-pregnen-3-one production by isolated ovarian follicle of amago salmon (Oncorhynchus rhodurus) in response to mammalian pituitary and placental hormones and salmon gonadotropin. Gen. Comp. Endocrinol. 1983; 52, 329-35.

[44] G Young, S Adachai and Y Nagahama. Role of ovarian thecal and granulosa layers in gonadotropininduced synthesis of a salmonid maturation-inducing substance (17 alpha, 20 betadihydroxy-4pregnen-3-one). Dev. Biol. 1986; 118, 1-8.

[45] R Billard. Reproduction in rainbow trout: Sex differentiation, dynamics of gametogenesis, biology and preservation of gametes. Aquaculture 1992; 100, 263-98.

[46] D Dietrich and HO Krieger. Histological analysis of endocrine disruptive effects in small laboratory fish. John Wiley \& Sons, New Jersey, 2009.

[47] R Cinquetti and L Dramis. Histological, histochemical, enzyme histochemical and ultrastructural investigations of the testis of Padogobius martensi between annual breeding seasons. J. Fish Biol. 2003; 63, 1402-28.

[48] FLL Nostro, FN Antoneli, I Quagio-Grassiotto and GA Guerrero. Testicular interstitial cells, and steroidogenic detection in the protogynous fish, Synbranchus marmoratus (Teleostei, Synbranchidae). Tissue Cell 2004; 36, 221-31.

[49] MC Uribe, HJ Grier and V Mejia-Roa. Comparative testicular structure and spermatogenesis in bony fishes. Spermatogenesis 2014; 4, e983400. 